\title{
KENNETH BOWMAN, ALBERTA LEPIDOPTERIST
}

LESLIE HENDRA, 8 Montana Gardens, London, SE26 5BF, U.K., E-mail: <lesliehendra@hotmail.com>

Kenneth Bowman was one of the earliest noteworthy collectors and compilers of Lepidoptera in Alberta. From the time of his arrival from England in 1904 to his death in Edmonton in 1955, he pursued this particular branch of natural history, travelling throughout southern Alberta and into the Rocky Mountains to build up a comprehensive and valuable collection of most of the species of butterflies and moths in the province. Acquired by the University of Alberta after his death, it forms a significant part of the Research Collection in the E. H. Strickland Entomological Museum. Although his collection has been documented and studied, not much is known in natural history circles about his character, background and the origin of his interest in collecting. It is the purpose of this article to supply some of the missing information.

Kenneth's lifelong devotion to natural history had a provenance that went back two generations. His grandfather, Robert Benson Bowman (1808-1882), was an early botanist in the northeast of England. Born in Richmond, North Yorkshire, Robert had become interested in botany as a youth and helped form a group of amateur collectors known as the Richmond Botanical Society. They roamed the countryside gathering and drying specimens, sometimes creating elaborate albums of pressed plants adorned with quotations from the poets. When Robert moved to Newcastle in about 1824, he continued collecting in his new environs and corresponded and exchanged specimens with some of the leading botanists of the day, including Sir William Jackson Hooker, Hewett Cottrell Watson, George Wailes and Nathaniel Winch.

Robert belonged to the Literary and Philosophical Society of Newcastle upon Tyne and was a founder, along with Albany and John Hancock and other prominent local naturalists, of the Natural History Society of Northumberland, Durham and Newcastle upon Tyne (NHS) in 1829, of which he was a Curator of Botany for many years. The Hancock Museum in Newcastle, the present-day manifestation of the NHS, holds his herbarium of mostly British plants. It was the age of natural history as a gentlemanly pursuit and of science as a profession, particularly in the industrial northeast of England. Robert was a chemical manufacturer, as was his father-in-law, the distinguished metallurgical chemist Hugh Lee Pattinson (1796-1858), who had a deep interest in many branches of science, including astronomy. Robert's three sons were members of the NHS. Henry (1843-1933), the eldest son and 
Kenneth Bowman's father, was an Honorary Curator of Mineralogy from 1864-1874, a Committee Member and a Secretary of the Society.

Henry married Isabella Catherine (Kate) Bell in Durham in 1867. The fifth of their seven children, Kenneth Bowman was born on 6 March 1875 in Barmston, Durham. The family moved fairly often. At the 1881 census, they were living with Kate's father, Thomas Bell, in Crosby Court, a large manor house in Thornton-le-Beans, North Yorkshire. Thomas, by profession an iron master and industrial chemist, was a keen amateur lepidopterist who collected in Britain and Europe. It was during his time at Crosby Court that Kenneth first became aware of the collecting of butterflies and moths as an engaging pursuit. Among the papers of his wife, Eva Bowman, is this note: "Ken Bowman's grandfather had a very large collection of European butterflies and $K B$ from the age of six years often accompanied him to the New Forest and other locations in England, on collecting trips." ${ }^{4}$

By 1884 , the family had moved to Clapham in South London and from 1889 to 1893 Kenneth studied at Dulwich College, the prestigious private school for boys. "All during this time," his sister wrote, "he was going on with his collection, going to Epping to see Grandfather's methods, and later to the New Forest, then spending week-ends in various parts of the country where rare specimens might be found." "Thomas Bell died in 1894 and Kenneth inherited his collection, which, together with his own, made a valuable one.

He began working in 1897 as a clerk to Blyth and Teesdale on the London Stock Exchange, becoming a Member in March 1900 and being authorised to transact business on the floor in 1901.11 After his mother's death in July 1903, however, he rather surprisingly cut short his career on the Exchange and sailed for Canada on 10 May 1904 aboard the Lake Manitoba, designated as a 'Farmer.' He was twenty-nine years old. ${ }^{8}$

The destination of the liner was Quebec and Kenneth disembarked there on 21 May 1904. Proceeding westward, he arrived in southern Alberta in the same year, where he worked for a time on a friend's ranch at Pine Lake near Red Deer. This coincides with the earliest part of his collection of Canadian Lepidoptera, which is from the Blackfalds-Red Deer area. By 1906, he was living in Edmonton and in the next year he began working as a crew member on the construction of the Grand Trunk Pacific Railway bridge at Clover Bar and took what amounts to a photo diary of the stages of its construction. When the foreman found out that he could do bookkeeping, he was given the job of running the office and put in charge of the huge payroll.

By 1909 , Kenneth was working for the Merchants Bank in Edmonton. He married Florence Vera Bleasdell (Vera), the second daughter of William $\mathrm{H}$. Bleasdell of Toronto, on 6 June 1912. It is not known where he met her, but they most probably married in Ontario. The marriage produced no children and was burdened by Vera's rapid descent into lifelong invalidism. Kenneth began a new profession as Chartered Accountant on 1 August 1914, when he was awarded his certificate by the Institute of Chartered Accountants of Alberta. In these and subsequent years, he managed to make ends meet but never became comfortable financially 
because, aside from the economic deprivations attending the two World Wars and the Depression, what he did make was largely spent on collecting butterflies and moths and, his other love, stamps of the world with a particular concentration on North America and the United Kingdom. His second wife was to write: "To him, money was merely a means of exchange." 4

His annotated checklist of more than 900 Macrolepidoptera of the province was published in 1919. It was a compilation of his own records and those of other collectors, and was founded on the checklist of Frederic Hova Wolley-Dod (1871-1919), the first comprehensive published checklist of Alberta Lepidoptera. ${ }^{2}$ Edgar Harold Strickland (1889-1962), the first entomologist at the University of Alberta, ${ }^{2}$ commented on his subsequent activities: "He now turned his attention increasingly to collecting the almost completely neglected Microlepidoptera of this part of Canada [...] Though he was fortunate, in his early years of collecting in this group, in obtaining taxonomic assistance in certain families from $\mathrm{Dr}$. J. $\mathrm{H}$. McDunnough in Ottawa, he was seriously handicapped in later years by being unable to find any specialists on this continent who were willing or able to classify the bulk of his steadily increasing Microlepidoptera." ${ }^{13}$ As his collection grew, he published a series of notes in The Canadian Entomologist over the next twenty-five years to correct and update the 1919 list. (See the bibliography at the end of this article.)

Kenneth had not forgotten his own, and Thomas Bell's, collection of butterflies in England but it was no longer of use to him. In early 1924, he wrote to his father in Kent, asking him to give the collection to a nearby museum. According to Folkestone Museum records, the butterflies were predominantly from Spain and Switzerland and mostly unlabelled. The years took a toll on the collection, however, and it was heavily weeded before World War II due to infestation, at least 3000 specimens being destroyed. In 1977, the collection, then in two cabinets, was reorganised into one twenty-drawer cabinet and this can still be seen at the museum today. ${ }^{7}$

Vera Bowman died in Edmonton on 3 March 1926 after her long illness. On 15 June 1927, Kenneth married the much younger Eva Grizelda Bowman Fisher (1896-1994), third daughter of retired dental surgeon, William Bowman Fisher of Greenock, Scotland. She had emigrated to Canada in May 1919 to help her eldest sister, Alison, wife of James Boyd McBride, the Alberta Provincial Court justice. The sisters had known the Bowmans well and, as part of the same social circle of 'expats,' had played golf, gone to parties and attended dances together. Eva was, in fact, engaged to another man, but Kenneth, a respectable one year after the death of his first wife, managed to persuade her to break the engagement and marry him instead. Eva used to relate how, in the early years of their marriage, when Kenneth wished to drive to the Rockies in search of butterflies, she would instantly agree and they would leave without further ado. She felt this was important, as Kenneth had been tied down for so many years with an invalid wife.

Their only child, Isobel Beatrice, was born on 30 March 1929. Kenneth was now fifty-five years old and his wife, thirty-two. They were living at 10240 Wadhurst Road, which had a sizeable back garden and a ravine in the front, 
and the household always included cats or Welsh Corgis, sometimes both, because of Kenneth's great fondness for animals. Still pursuing his career as a chartered accountant and auditor, he worked for McDougall Court Limited, the Blue Willow Tea company, a mine in Nordegg, the Scouts and Guides of Edmonton and other firms around the province. Travelling gave him the opportunity to add to his collection, which ultimately comprised many species not only from the Edmonton area but also from Nordegg, Pocahontas, Jasper, Blairmore and other areas. He made frequent forays to the 'muskeg' at Stony Plain and even collected in his own garden. His daughter recalls, "The butterfly net was at hand summer-long and tea could be interrupted by a sudden sighting, a quick stalking and a swooping putaway for setting later. The 'killing bottle' was there also, but out of my early awareness, I think. Later it fascinated me and was a very quick death to all who entered there." ${ }^{n}$ The net he used was a folding model, which he carried in his jacket pocket at all times. Although he was six feet one inch tall,. Kenneth had small hands and feet (a size eight shoe) and his small hands made him particularly dexterous at setting tiny specimens. It was utterly taboo to disturb him while he was working on his collection in the lofty attic chamber of the house.

Isobel remembers Kenneth describing how some tough miners in Nordegg had expressed scorn behind his back for the 'sissy' occupation of a man hunting butterflies and using a big net to do so. "When he was told this, he returned to the mine office the following day and put it about, very casually in conversation, that he'd got $\$ 10$ for the butterfly of the day before! No one said much but among the miners word got around fairly fast. He wasn't 'crazy.' He was netting money and knew which ones to catch and their value! This was depression time. Everyone who was working was poorly paid, but even so, lucky just to have a job. Ken's story brought great respect, even interest, and no one knew he'd made it all up." 6 He may have made up that story but it was true that butterflies had commercial value.

Although religion was important to Eva, it did not play a large part in Kenneth's life. Rather, a feeling of curiosity, awe and respect for nature appears to have satisfied many of his needs. In keeping with the Bowman family devotion to natural history, he taught his daughter from childhood to be keenly aware of what lay around her. To encourage her to learn about gardening, he dug a small garden for her sole use and to include her in his passion for butterfly collecting, he gave her a cork-lined box, pins, her own net, supervised access to the 'killing jar' and instruction in technique. Life in all its forms was to be explored and enjoyed, not feared or hated. Snakes and bats were admired for their beauty, the family pets studied for their behavioural traits, electrical storms watched for their spectacular display and the National Geographic pored over and discussed. Death was faced without compromise. When a pet died, it was wept over and then buried. Isobel early recognised this 'dead-stop' to life. What existed beyond it was only a feeling of missing and memories for sharing. ${ }^{6}$

Although known to have a quick and rather dramatic temper on occasion, Kenneth seldom got angry with his daughter. One exception was "my early opening of a few of his air-tight butterfly cases. I was under six because I can only just remember the big cases being 
as easy as pulling out a book. Wings flew off apparently, and coloured dust - a lot of damage to a labour of years, this part of his collection. After this the cases all had two strings of wire along the shelf-fronts. I got a spanking for this." Even when young, Isobel recognised her father was different from other fathers: he was twenty years older than them - and his wife. He was stable and confident as befits an older man but also took delight in childish and exuberant things: fireworks, early London music hall songs, games, puzzles, nonsense rhymes, ridiculous stories and practical jokes.

Kenneth usually worked in the mornings and early afternoons, returning with various companies' audit books as his 'homework' but during the Second World War, work thinned out. The family sold the car and Kenneth either walked to town and back in all seasons or cycled - singing and whistling all the way, to the surprise of pedestrians - a fifty-two-block round trip. He was about seventy by then.

His daughter Isobel married Roy Hendra, of another old Edmonton family, on 23 June 1951. This was the same year in which Kenneth brought out An Annotated List of the Lepidoptera of Alberta, an updated and much expanded version of his 1919 checklist. "[It] was among the most comprehensive regional checklists of the time. It contained 140 butterfly species, 857 macromoth species, and 638 micromoth species." ${ }^{\prime 9}$

Kenneth lived for another four years after that and was able to enjoy two years of my, his first granddaughter's, life. He was to have three grandchildren

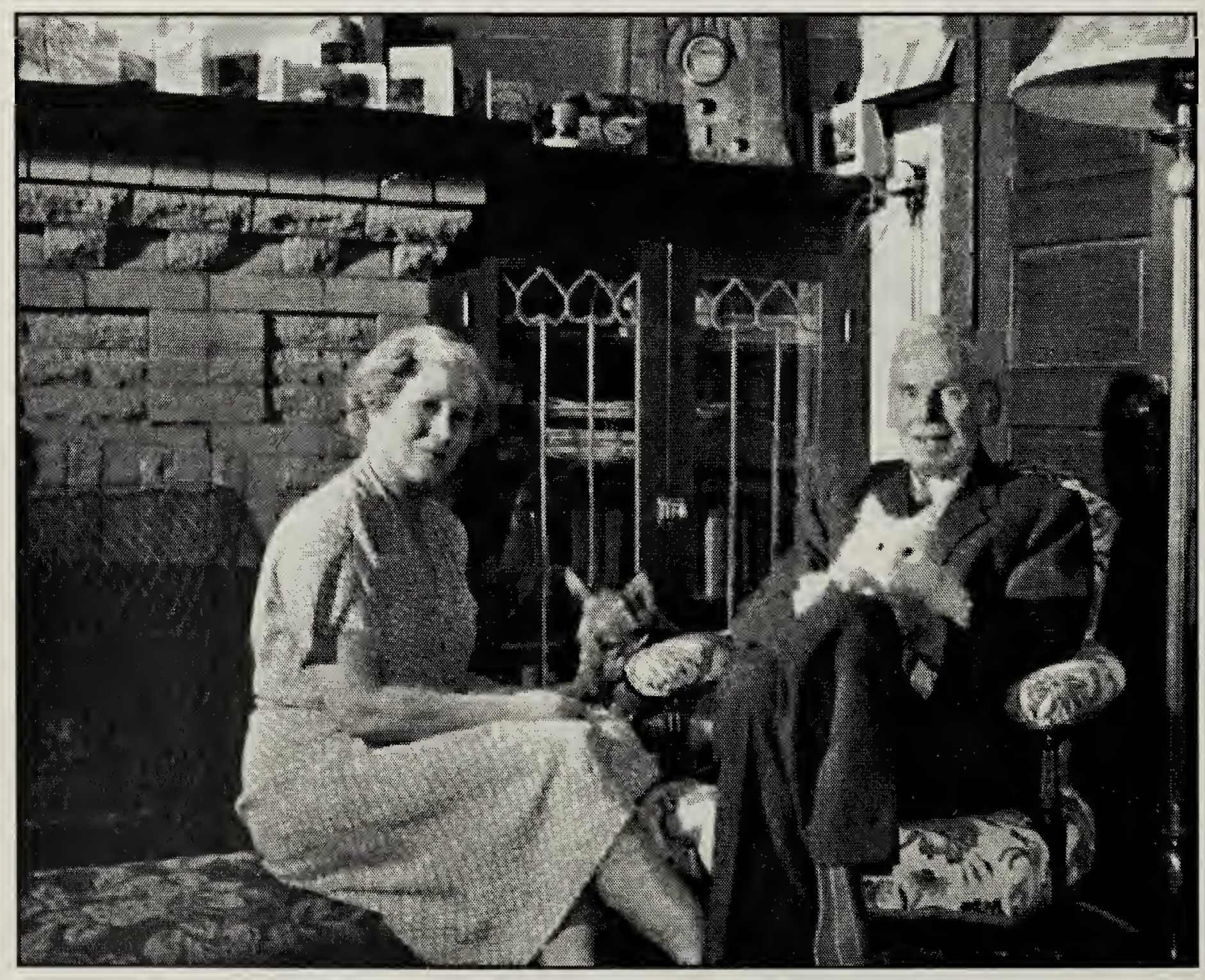

Kenneth and Eva Bowman in Edmonton, ca 1950. 
but only I benefited, however briefly, from his kindness and delight in all life. His health had finally started to deteriorate and perhaps this was the reason he was not a charter member of the Entomological Society of Alberta (ESAB), founded in Lethbridge in November 1952. He was, however, a member of the society in 1953 and 1954. Greg Pohl of the Northern Forestry Centre and long-time ESAB member writes, "The first annual meeting of the ESAB was held in Calgary, October 2-3, 1953. Mr. Bowman was there, and he helped lead a discussion entitled 'The Future Role of Entomology in Alberta', where the society shaped its purpose and direction."(Greg Pohl, pers. comm., 2005)

He continued, despite his poor health, to correspond with Dr. McDunnough and staff of the Canadian National Collection of Insects in Ottawa. In December 1954, having just recovered from an illness, he was preparing to send a particular set of specimens to Ottawa for identification. He wrote, "I don't want to send everything I have as my collecting days are over \& I shall not be able to replace anything $[\ldots]$ My series are not long, but are the pick of 40 years collecting so you will realize I don't want to risk the whole lot." ${ }^{5}$ He sent more specimens in April 1955 but that may have been the last shipment. His illness returned. A last-chance operation failed to save him and he died on 25 September 1955 , aged 80 . He is buried in the Edmonton Cemetery next to his first wife, and the inscription on the stone simply reads "KENNETH BOWMAN 1875 - 1955." The ESAB printed an obituary that concluded, "For over fifty years his spare time was devoted to painstaking collection and to the meticulous care which he gave his specimens. If the Society can raise one amateur to emulate him in a generation it will serve its purpose well."1 The fifty years mentioned were the ones spent collecting in Canada; his earlier activities in the U.K. were not known.

Later in 1955, Eva Bowman sold his collection of some 13,000 specimens to the University of Alberta. According to a recent paper, "One of the most active parts of the Strickland Museum is now the Bowman Collection of moths and butterflies, reflecting the recent arrival of [Dr. Felix Sperling] [...] The Bowman Collection is now one of the focal points of the Alberta Lepidopterists' Guild, a group of several dozen enthusiasts from all walks of life who have been the driving force behind the development of the entomology virtual museum."12 Previous to this, it had been "used extensively by C. D. Bird et al. (1995) for the preparation of Alberta Butterflies, by researchers at the Canadian Forest Service in Edmonton, and also occasionally by other taxonomists." (Greg Pohl, pers. comm., 2005)

To clarify the nature of Kenneth Bowman's collection from the viewpoint of twenty-first century entomologists, Greg Pohl states: "The entire Lepidoptera fauna of Alberta is thought to contain 2500 to 3000 species. In an update to Bowman's 1951 checklist (Pohl et al, in preparation), approximately 2200 species were known as of 2005. Some of the records since Bowman's time have come from specialized habitats. Modern roads, and lights and generators, have aided considerably. Many of the new records represent species that have only been recognized and described since Bowman's time. Recent examination of specimens in Bowman's collection has revealed that he had collected many of these unnamed species as 
well but obviously had filed them under other names."(Greg Pohl, pers. comm., 2005)

In December 2004, his collection was featured as one of the contributions of the University of Alberta Museums to "celebrate inspiration and the City of Edmonton Centennial." 10 Posters of him in his later years, with butterflies superimposed, were seen around the city, a fine tribute to his work. Like his grandfather, the botanist Robert Benson Bowman, Kenneth worked with local natural history groups, corresponded and exchanged specimens with specialists, collected tirelessly while maintaining a career in a wholly unrelated field, and made a significant contribution to the knowledge of local natural history. He had an extraordinarily long collecting career of over seventy years, aided by excellent physical fitness and the indulgence of his family. It is no exaggeration to say that he devoted his life to butterflies and moths.

1. ANONYMOUS. 1956. Obituary. Kenneth Bowman, 1875-1955. Proceedings of the 3rd Annual Meeting of the Entomological Society of Alberta, Calgary, Alberta, October 7-8, 1955, p. 28.

2. BIRD, C.D., et al. 1995. Alberta Butterflies. Edmonton, The Provincial Museum of Alberta

3. BOWMAN, Alice. April 1956. Memories of Kenneth Bowman (unpublished)

4. BOWMAN, Eva. Undated note in personal papers

5. BOWMAN, Kenneth. 11 December 1954. Letter. In The Douglas C. Ferguson Papers, 1929-2002. Held by Smithsonian Institution Archives, Washington DC

6. ELIAS, Isobel B. 2001-2004. Memories of Kenneth Bowman (unpublished)

7. KENT COUNTY COUNCIL, Folkestone Library. 2 November 1999. Letter
8. Outgoing passengers list. 10 May 1904. Held at National Archives, Richmond, London, England

9. POHL, GREG R. and B. CHRIS SCHMIDT. 2003. Alberta's Lepidoptera fauna: the last 100 years. Proceedings of the 50th Annual Meeting of the Entomological Society of Alberta. September 2003.

10. Poster. 2004. 'Edmonton Inspires, Stories from the University of Alberta Museums.' University of Alberta

11. Records of the London Stock Exchange. 18971904. Held at Guildhall Library, London, England

12. SPERLING, F. et al. 2003. Unlocking the Legacy of Alberta's Natural Science Collections. UMAC 2003 Conference, September 21-26.

13. STRICKLAND, E. H. January 1956. The Canadian Entomologist 88:1, p.44

\section{Kenneth Bowman: Bibliography}

1919. Annotated Check List of the Macrolepidoptera of Alberta. Alberta Natural History Society, Red Deer

1921. Annotated Checklist of the Macrolepidoptera of Alberta. Additions, 1919. The Canadian Entomologist 53:1314

1921. Annotated Checklist of the Macrolepidoptera of Alberta. Additions, 1920. The Canadian Entomologist 53:211212

1923. Annotated Checklist of the Macrolepidoptera of Alberta. Additions, 1921. The Canadian Entomologist 55:7172

1924. Annotated Checklist of the Macrolepidoptera of Alberta. Additions. The Canadian Entomologist 56:189-191

1928. Additions to Annotated Checklist of the Macrolepidoptera of Alberta. The Canadian Entomologist 60:117-118

1934. Annotated Checklist of the Macrolepidoptera of Alberta, Additions and Corrections. The Canadian Entomologist $66: 131-132$

1938. Additions and Corrections to Checklist of the Macrolepidoptera of Alberta. The Canadian Entomologist 70:260-261

1942. A Note on Colias eurytheme Bdv., with description of a new race. The Canadian Entomologist 74:25

1944. Additions and Corrections to Checklist of the Macrolepidoptera of Alberta. The Canadian Entomologist 76:191-192

1951. An Annotated List of the Lepidoptera of Alberta. Canadian Journal of Zoology 29:121-165 